\title{
Megaloblastic anaemia due to trimethoprim-sulphamethoxazole therapy in uraemia
}

\author{
G. M. YUILL \\ M.B., CH.B., M.R.C.P., B.Sc. \\ University Hospital of South Manchester
}

\begin{abstract}
Summary
A patient is described in whom malignant hypertension led to oliguric renal failure. A course of trimethoprim and sulphamethoxazole (co-trimoxazole) was prescribed for an intercurrent urinary tract infection and appeared to precipitate a megaloblastic anaemia which responded satisfactorily to folic acid.
\end{abstract}

\section{Introduction}

Sulphonamides interfere with the conversion of para-aminobenzoic acid to dihydrofolic acid. Trimethoprim interferes with the conversion of dihydrofolic acid to tetrahydrofolic acid by interfering with the enzyme dihydrofolic acid reductase. The bacterial enzyme is $\times 10,000$ more sensitive than the mammalian enzyme to trimethoprim. Usually this selective toxicity enables one to eradicate bacterial infection without significantly interfering with the metabolism of the mammalian host. However, there are several reports demonstrating an effect of the trimethoprim-sulphonamide combination on human folic acid metabolism.

Kahn, Fein \& Brodsky (1968) administered trimethoprim to a group of patients with normal blood counts and blood urea. One patient's haemoglobin fell from 14.0 to $8.7 \mathrm{~g} / 100 \mathrm{ml}$; another's platelet count fell from 200,000 to $60,000 / \mathrm{mm}^{3}$. They also observed a rise in the polymorphonuclear lobe count, a rise in FIGLU excretion, and giant metamyelocytes and transitional megaloblastic erythroid changes in the bone marrow.

They treated a second group of patients with trimethoprim and sulphamethoxazole (co-trimoxazole) and reported the following abnormalities: leucopenia, granulocytopenia, thrombocytopenia, and an increase in FIGLU excretion. Bone marrows were not examined in this group.

Allison et al. (1969) and Hulme \& Reeves (1971) also reported similar abnormalities.

The current case report is of a patient who was given co-trimoxazole whilst oliguric and who developed severe megaloblastic anaemia, thrombocytopenia and mild leucopenia.

\section{Case history}

J.B. was a 40-year-old housewife who was admitted to Withington Hospital in June 1971. Three months before admission she developed breathlessness on exertion and general malaise. She was discovered to have severe hypertension which proved difficult to control and her renal function had deteriorated steadily. She was transferred to Withington Hospital.

On examination she was pale, breathless and anxious. BP $200 / 125 \mathrm{mmHg}$; CVP elevated to $6 \mathrm{~cm}$ $\mathrm{H}_{2} \mathrm{O}$. There were crepitations at both lung bases, and oedema of the face, sacrum and ankles. She had a grade 4 hypertensive retinopathy. She had psoriatic patches over the trunk and her scalp and a few psoriatic pits on the nails. There was thickening of the metacarpophalangeal joint of the left thumb and the left little finger and there was slight thickening of the periarticular tissue around the knees. A clinical diagnosis was made of essential hypertension entering a malignant phase with renal failure. In addition she had a mild inactive psoriatic arthropathy.

Investigations. $\mathrm{Hb} 6.5 \mathrm{~g} / 100 \mathrm{ml}$, WCC $12,000 / \mathrm{mm}^{3}$, platelets $40,000 / \mathrm{mm}^{3}$, reticulocytes $9 \%$, blood urea $254 \mathrm{mg} / 100 \mathrm{ml}$, sodium $142 \mathrm{mEq} / 1$, potassium 4.6 $\mathrm{mEq} / \mathrm{l}$, chloride $90 \mathrm{mEq} / \mathrm{l}$, urea clearance $<1 \mathrm{ml} /$ min. Urine volume about $200 \mathrm{ml} /$ day. Serum albumin $3.5 \mathrm{~g} / 100 \mathrm{ml}$, globulin $3.1 \mathrm{~g} / 100 \mathrm{ml}$, bilirubin, thymol turbidity, alkaline phosphatase, transaminases and serum protein electrophoresis normal. Calcium $9.8 \mathrm{mg} / 100 \mathrm{ml}$, phosphorus $7 \cdot 4$ $\mathrm{mg} / 100 \mathrm{ml}$. Serological tests for SCAT, latex, antinuclear factor, LE cells, WR, Coombs' test were negative. The ASOT was normal. The kidneys were 11 and $11.5 \mathrm{~cm}$ in length. The electrocardiograph showed left ventricular hypertrophy and strain and left axis deviation.

Progress. She was put on an $18 \mathrm{~g}$ protein, $20 \mathrm{mEq}$ sodium Giovanetti diet with vitamin and methionine supplements. Blood pressure was controlled with methyldopa $250 \mathrm{mg}$ q.d.s. and she had several peritoneal dialyses in order to remove excess fluid. Investigations revealed the presence of a significant 
growth of coliforms sensitive to Septrin in the urine on four occasions and on 25 August she was put on tabs. Septrin 1 q.d.s. (sulphamethoxazole $1.6 \mathrm{~g}$ and trimethoprim $320 \mathrm{mg}$ daily) in addition to the above regimen. She was treated with Septrin until 14 September when the urine became sterile. During this period she was found to have a moderate reticulocytosis, a low platelet count, and significantly raised fibrin degeneration products. The haemolytic uraemic syndrome was diagnosed with significant intravascular coagulation as a complication of malignant hypertension and in view of her serious clinical state, on 9 September, she was started on intravenous heparin therapy which continued until 15 September. During this time it was noticed that her reticulocyte count and platelet count were falling.

The falling platelet count was attributed to haemolytic uraemic syndrome, but the fall in the reticulocyte count was not explained. At the same time it was noticed that the haemoglobin was falling steadily despite no overt source of blood loss and reasonable control of her uraemia. A blood film at this time showed some hypersegmented polymorphs, and occasional macrocytes. The platelet count reached 40,000 and a sternal marrow was performed which demonstrated megaloblastic changes in the erythroid series and occasional giant metamyelocytes and raised iron stores. She was treated empirically with $1000 \mu \mathrm{g}$ of vitamin $B_{12}$ daily, $15 \mathrm{mg}$ of folic acid parenterally daily from 10 September for 1 week and the Septrin was stopped on 13 September. On 16 September her haemoglobin was rising and she had a brisk reticulocytosis and the platelet count had reached 200,000 . The serum $B_{12}+$ folate analysis was then returned, the $B_{12}$ was $295 \mathrm{pg} / \mathrm{ml}$ and the serum folate level was $0 \cdot 1 \mathrm{ng} / \mathrm{ml}$ and further $B_{12}$ therapy was stopped (Fig. 1).

She was established on intermittent haemodialysis on 2 October, with the blood urea ranging from 60 to $80 \mathrm{mg} / 100 \mathrm{ml}$ and by 12 October the haemoglobin was $6.9 \mathrm{gm} / 100 \mathrm{ml}$, white cells $9000 / \mathrm{mm}^{3}$, and reticulocytes $6 \%$. A repeat sternal marrow was performed (15 October) and showed normoblastic erythropoiesis with strikingly deficient iron stores, a finding in marked contrast to the previous marrow. There was defective haemoglobinization and she is currently being treated with a course of intravenous iron. On 23 November her haemoglobin was 11.6 $\mathrm{g} / 100 \mathrm{ml}$.

\section{Discussion}

We think that the unusual degree of interference with human folic acid metabolism found in this case was due to a combination of several factors. Firstly there was dietary deficiency of folic acid, secondly, extra utilization of folic acid due to marrow hyperplasia compensating for a haemolytic anaemia,
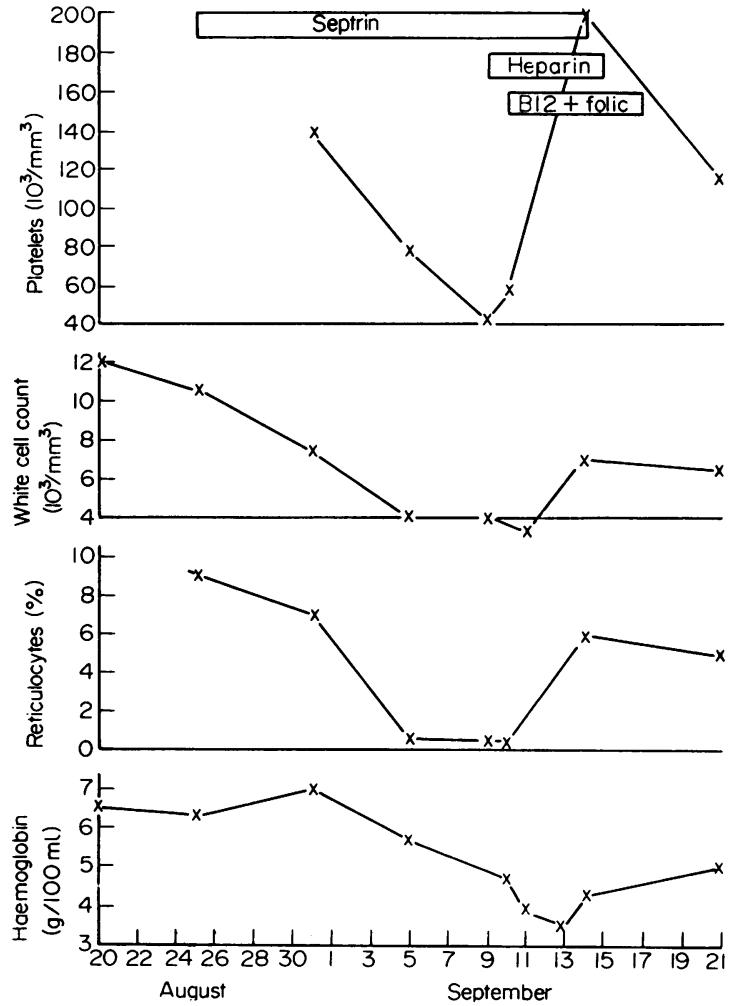

FIG. 1. Sequential changes in the patient's blood count, and corresponding treatment.

thirdly, folic acid loss from the body by peritoneal dialysis, and finally there was the known antagonism of folate metabolism by the combination of trimethoprim and sulphamethoxazole.

The patient had been uraemic for 12 months and during this time ate poorly. This may well have critically depleted, if not have exhausted, her body stores of folic acid. She was then put on a Giovanetti diet containing $18 \mathrm{~g}$ of protein daily. Sevitt \& Hoffbrand (1969) estimated that a $20 \mathrm{~g}$ protein diet supplies $150-300 \mu \mathrm{g}$ of folic acid daily, after loss caused by cooking. They also demonstrated that peritoneal dialysis causes a significant loss of folate from the body.

As the estimated folic acid requirement is $50-100$ $\mu \mathrm{g}$ daily (De Gruchy, 1970) it is obvious that the patient's dietary folic acid intake was at a critical level. It is interesting to recall that Kahn (1968) showed in his study that haematological interference by co-trimoxazole could be prevented by $400 \mu \mathrm{g}$ folic acid daily. Sharpstone (1969) showed that defective excretion of co-trimoxazole did not occur until creatinine clearance fell below $3.5 \mathrm{ml} / \mathrm{min}$. Therefore, our patient whose clearance of creatinine was approximately $1 \mathrm{ml} / \mathrm{min}$ would have developed 
drug retention at a time when her dietary intake was below the level of $400 \mu \mathrm{g}$ folic acid-the level shown by Kahn to be necessary to counteract co-trimoxazole antagonism of folic acid.

In addition to these factors, however, it may be expected that her folic acid consumption was much higher than normal as she had evidence of a significant haemolytic anaemia. It is well known that a haemolytic anaemia may cause megaloblastic anaemia due to depletion of body folic acid storesChanarin, Dacie \& Mollin (1959). On the other hand, Clarkson et al. (1970) did not comment on megaloblastic anaemia in his cases with the haemolytic uraemic syndrome.

Finally, during the later stages of her illness, she had several peritoneal dialyses. Sevitt \& Hoffbrand (1969) showed that peritoneal dialyses caused a striking fall in serum folic acid and this was undoubtedly a further significant factor in the development of folic acid deficiency in our patient. One must add that the low serum folic acid level does not prove folate deficiency, as the bacteriological assay may have been upset by the co-trimoxazole, although it is strange that a similar mechanism did not interfere with the estimation of vitamin $\mathbf{B}_{\mathbf{1 2}}$.

\section{Conclusion}

We would suggest that in this situation co-tri- moxazole is administered with small doses of folic acid and that, in fact, the Giovanetti diet itself might be supplemented by a small daily supplement of folic acid.

\section{References}

Allison, M.E.M., Kennedy, A.C., McGeachie, J. \& McDonald, G.A. (1969). Sulphamethoxazole-trimethoprim therapy in urinary tract infection with reference to its haematological effects. Scottish Medical Journal 14, 355.

KAHN, S.B., FeIN, S.A. \& Brodsky, I. (1968) Effects of trimethoprim on folate metabolism in man. Clinical Parmacology and Therapeutics, 9, 550.

Chanarin, I., Dacie, J.V. \& Mollin, D.L. (1959) Folic acid deficiency in haemolytic anaemia. British Journal of Haematology, 5, 245.

Clarkson, A.R., Lawrence, J.R., Meadows, R. \& SEYMOUR, A.E. (1970) The haemolytic syndrome in adults. Quarterly Journal of Medicine, 39, 227.

DeGruchy, G.C. (1970) Clinical Haematology in Medical Practice. 3rd edn, p. 130. Blackwell Scientific Publications, Oxford.

Hulme, B. \& ReEves, D.S. (1971) Leucopenia associated with trimethoprim - sulphamethoxazole after renal transplantation. British Medical Journal, 3, 610 .

SevitT, L.H. \& Hoffbrand, A.V. (1969) Serum folate and vitamin B12 levels in acute and chronic renal disease. Effects of peritoneal dialysis. British Medical Journal, 2, 18.

ShaRPSTONE, P. (1969) The renal handling of trimethoprim and sulphamethoxazole in man. Postgraduate Medical Journal, Suppl. 45, 38.

\title{
Foetus acardius amorphus
}

\author{
Brian Alderman* \\ M.B., CH.B., M.R.C.O.G. \\ Clatterbridge Hospital, Cheshire
}

\section{Summary}

A case of acardius amorphus is reported. The rarity of foetal monsters without a functioning heart is emphasized and the method of classification reviewed. The theories of teratogenesis are discussed. Evidence is presented in support of the theory that there is a primary failure of the organ to develop. The possibility of anoxia and nutritional deficiency of the foetus being solely responsible for the malformation seems unlikely.

\footnotetext{
* Present address: Department of Obstetrics and Gynaecology, University of Liverpool.
}

Gross foetal malformations of the acardiac variety are exceedingly rare. As the name implies, the chief abnormality common to all varieties of the monster is the lack of a functioning heart.

The monster is always one of a pair of uniovular twins, but has been reported in a triplet pregnancy (Ross, 1951). The other foetus, whose heart provides the circulatory force for both twins, is usually normal.

The incidence of acardiac monsters is difficult to ascertain. However, Kappelman (1944) has estimated that they occur approximately once in 34,600 births. 